\title{
HIGH SPEED RAILWAY LINES - FUTURE PART OF CZECH RAILWAY NETWORK?
}

\author{
LUKÁŠ TÝFA ${ }^{a, b, *}$, DAVID VODÁK ${ }^{b}$ \\ ${ }^{a}$ Department of Logistics and Management of Transport, CTU in Prague, Faculty of Transportation Sciences, \\ Prague, Czech Republic \\ ${ }^{b}$ Department of Transportation Systems, CTU in Prague, Faculty of Transportation Sciences, Prague, Czech \\ Republic \\ * corresponding author: tyfa@fd.cvut.cz
}

Abstract. The paper first describes high speed rail generally and explains the relationship between high speed and conventional railway networks (according to the vehicle types in operation on the network). The core of the paper is comprised of the methodology for choosing the best route for a railway line and its application to the high speed railway connection Praha - Brno. The Algorithm used assumes the existence of more route proposals, which could be different in terms of the operational conception, line routing or types of vehicles used. The optimal variant is the one with the lowest daily cost, which includes infrastructure and vehicle costs; investment and operational costs. The results from applying this model confirmed the assumption, that a dedicated high speed railway line, only for high speed trains, has the same or lower investment costs than a line for both high speed and conventional trains. Furthermore, a dedicated high line also has a lower cost for infrastructure maintenance but a higher cost for buying high speed multiple units.

KEYWORDS: high speed rail, railway network, investment costs, operational costs.

\section{RAILWAY NETWORK}

Every transportation system has its advantages and disadvantages. This means, that there is a perfect match for every single transport demand (from the sum of all costs - externalities included). In general, railway transportation appears to be the perfect transport system for the backbone of urban and intra-urban transport, regional transport and long-distance continental transport. It also works perfectly in freight transport, as a part of combined transport, or regular transportation between branches. Currently railway transportation in the Czech Republic cannot work optimally because [1]:

- conventional mainlines, with standard parameters (from the Czech point of view - railway lines with more tracks, maximal speed $120-160 \mathrm{~km} / \mathrm{h}$ and electric traction), are almost out of capacity and routes in graphical time table cannot be assigned appropriately

- some segments have high transport potential due to their route, but their technical and operational parameters (low capacity, low speed, low load class, often speed restrictions) make them unattractive for carriers (transport operators)

- on some routes the traffic demand is not satisfied at all or it is satisfied by another mode of transportation, despite the fact, that these routes have perfect conditions for railway transportation

- on the other hand, there are some effectively obsolete sections of railway line without any current use and without hope for future transport potential

One possible solution, which could improve this situation, is the building of a high speed railway system 1 . The high speed railway system and the conventional railway system are both parts of the general railway system - see directive EU about interoperability of railway system [2]. High speed railway lines include [2]: newly built lines for speeds up to $250 \mathrm{~km} / \mathrm{h}$, upgraded conventional lines for speeds of approximately $200 \mathrm{~km} / \mathrm{h}$ and upgraded conventional lines with special attributes. New high speed railway line is an adhesion railway line (usually track gauge 1,435 mm and electric traction), which has sections with a maximal speed of $250 \mathrm{~km} / \mathrm{h}$, and which are long enough so vehicles can reach this speed. Combinations of these sections and upgraded sections (usually for the speeds up to $200 \mathrm{~km} / \mathrm{h}$ ) create the high speed railway network. The complexity of railway transportation is mainly caused by strong connectivity between the subsystems, the different life-cycle of the subsystems and the long time period between launch of a project and launch of its regular operation. Changes in the operational conception (train traffic schedule) could be made in days and usually lasts one year. It usually takes several years to prepare a railway vehicle for operation and its servisable life is usually between twenty and thirty years. The building of new railway infrastructure usually takes a period of between ten and twenty years (including design and all administrative procedures) and its period of operation could be (with the proper maintenance) a hundred years 
or so. The situation is similar for high speed railway systems, but due to the higher speed, the connection between subsystems is even stronger.

\section{Typology of THE CONNECTION BETWEEN HIGH SPEED AND CONVENTIONAL NETWORK}

According to the strength of connection between the high speed and conventional railway system, we may establish four basic approaches 1]:

(1.) Completely segregated railway systems

High speed and conventional lines networks are completely separated and independent in this case. Conventional trains are using only the conventional lines and high speed trains are using only high speed lines. The advantage of this approach is that we can adjust the parameters of the line to meet the requirements of only high speed trains which usually leads to a smaller radius of curves, higher longitudinal gradients and lower investment costs. The main disadvantage is the impossibility of profiting from connection between the networks and the necessity of a really strong transport flow (passengers and so trains) to make this kind off network economically effective. We can find this kind of network in Japan where the main reason for existence of this system is different track gauge on both railway networks.

(2.) Conventional trains are operating on the high speed railway network

In this case, the conventional and high speed networks are connected, but only conventional trains (freight or passenger) are using both networks. Conventional trains have to be modified for the operations on the high speed railway lines, especially for the safe passing of high speed trains. The main advantages of this approach are: the possibility of bypassing sections where demand exceeds capacity on the conventional network, the speeding up of conventional trains and/or increasing the usage of high speed railway lines. The disadvantage of this approach is the necessity of adjusting the parameters of the high speed lines to conventional vehicles, which have lower transport performance and lower maximum vehicle speed. In order to adjust the specifications we have to increase the radius of curves and reduce longitudinal gradients which results in higher investment costs. This approach also increases the wear on railway infrastructure (especially rails), because the speeds of the operated trains are different. The higher the difference between speeds is, the more strained the superstructure is. At the same time, the capacity of the high speed line is decreased, because parallel graphical timetables cannot be designed due to the difference in the speeds of trains which results in the need to build passing points, which allow trains with different speeds to pass each other. An example of this solution can be seen in Spain, where there are different track gauges on conventional and high speed networks, but where some of the conventional trains are also operating on the high speed lines. These vehicles can change their wheel gauge thanks to the special construction on undercarriage and superstructure.

(3.) High speed trains are operating on conventional network

In this case the conventional and high speed networks are connected, but only the high speed trains are using both networks; they use the high speed line for the most of train line length. This solution allows high speed trains to get closer to the place of traffic demand without the need for a high speed line. On the other hand, the operation of high speed multiple units on the conventional line is more expensive than operating just conventional trains. The difference in costs is not big, but it still exists - mainly because of higher performance, higher safety and reliability requirements, and better parameters of high speed multiple units (higher mechanical body resistance to air pressure - train passing, running in tunnels). Another disadvantage is the higher probability of accidents on the conventional network, which can lead to transition of delay from the conventional network to the high speed network. An example of this solution could be found in France, where high speed trans operate on conventional lines in order to get closer to city centres or to reach destinations, which are not yet connected to high speed network.

(4.) High speed and conventional trains are both operating on both networks

In this case the conventional and high speed networks are connected and both types of trains are using both networks. This solution uses the maximal potential of connection of both networks. It also brings the possibility of building the high speed railway line in stages, so that non-related segments of the high speed railway line can be built in order to fix the worst issues on the conventional network. The disadvantages are: the higher probability of the accidents on the conventional network, which can lead to a delay in the transition from the conventional network to the high speed network, complicated train traffic schedule designs and stricter the need for higher specifications of the high speed line. This solution also results in the less efficient use of high speed multiple units, because they cannot reach their full potential on the conventional network. An example of this approach can be found on many newly built and upgraded high speed railway lines in Germany. The traffic consists not only of the high speed multiple units and regional passenger trains but also of the freight trains (mostly in the night) - see below. 


\section{Freight trains on High SPEED LINES}

There are two basic approaches to freight operation on high speed lines. Those approaches are distinguished according to the parameters of freight trains (length, weight, weight on axle, performance). In the first case, the freight train has the same parameters as the passenger train; the difference is only in the transported goods (mail, goods on pallets, special small containers). In the second case the freight train consists of classic freight carriages. In the first case, the freight trains can be treated as passenger trains. In the second case, we have to make some special safety measures to allow for the coexistence of the freight and passenger trains, which usually means, to the determination of different time periods for passenger trains and for freight trains.

\section{General benefits of high speed RAILWAY NETWORK}

- quantitative - high speed railway lines increase the overall capacity of the railway network but it is important connecting new lines to the nodes must not cause traffic restrictions or instability on the existing conventional network

- qualitative - better transportation by cutting the travel times between main cities

- economical for railway carriers (transportation operators) - high speed multiple units are going to run more distance per day and more distance on high speed lines

- decreasing intensity of road transportation by moving the transport flows to the railway with significant benefits in terms of safety and the environment

- establishing connections between trains in periodical timetable

- secondary effects - increasing share of electrical traction (and so production decreasing of carbon dioxide and harmful exhalation, possibility of independence from hydrocarbon fuels)

\section{Methodology of PROJECT COMPARISON AND ITS APPLICATION}

The main goal of this paper was to introduce an algorithm for choosing the best route for a railway line and its application to the high speed railway connection Praha - Brno. The algorithm assumes the existence of more route proposals, which could be different in operational conception, line routing or types of vehicles. The optimal variant (according to the algorithm) is the one with the lowest daily cost, which includes infrastructure and vehicle costs and investment and operational costs. The algorithm does not take into account the dividing of the railway transportation among subjects - railway transportation is assumed as one unit. This unit consists of owning the railway, operating the railway and operating the railway transportation.

The methodology is showed in the six connected tables. The first table, "Operation", shows operated lines on the line; then number of trainsets (multiple units) and the daily time costs of trains in operation are calculated. The second table, "Trainsets", shows the trainsets (multiple units) operated on the line and its results are the daily costs for buying trainsets. Table III. "Unitary infrastructure investment costs", shows aggregated investment costs for the infrastructure - it is used for drawing up a budget. Table IV. "Infrastructure and operation on it" is designed to calculate the infrastructure investment and train operational costs according to energy consumption. Table V. "Track sections with constant operation" calculates the infrastructure and trains operating costs and the infrastructure investment costs. Table VI. "Recapitulation" shows the unitary daily costs from the previous tables and also divides daily the cost between the subjects on the railway (infrastructure manager, carriers - railway operators, infrastructure owner).

To demonstrate the algorithm, two variants of high speed railway line Praha - Brno were evaluated. The first variant is from the study designed by SUDOP PRAHA AG in 2010 3, which is called Study 2010. For the purposes of demonstration, variant $\mathrm{H} 4$ from the Study 2010 was chosen. The second variant is from the study LT 2012, which is Study 2010 with alterations from Lukáš Týfa, one of the authors of this paper [1. Study 2010 assumes following operational conception - the high speed railway network will be used both by high speed and conventional trains, high speed trains will be mainly operated on the high speed railway lines and only temporarily on conventional lines, conventional trains will use connections between both networks to enter the high speed lines and use them for the part of their journey.

Variant LT 2012 assumes the same horizontal alignment as study 2010, but makes changes in the vertical alignment - maximal proposed longitudinal gradient value is $35 \%$. This is a consequence of the change in the operational conception - line segment Benešov Brno will be used only by high speed multiple units, those which can be easily operated in such a longitudinal gradient. A change in the operational conception could also cause a lowering of the minimal curve radius, but the author of variant LT 2012 thinks, that this value was defined too benevolent in Study 2010, so no changes were made in this value [4, 5]. Both variants have same maximal proposed speed - 350 $\mathrm{km} / \mathrm{h}$, although regular operations with a speed 350 $\mathrm{km} / \mathrm{h}$ do not seem very effective (only a minor cutting in travel times, but a major increase of the operational costs). The main design parameters (track geometry characteristic) of Study 2010 and LT 2012 are displayed in Table 1 


\begin{tabular}{|c|c|c|c|c|c|c|c|c|c|}
\hline \multirow{2}{*}{\multicolumn{2}{|c|}{$\begin{array}{c}\text { study/variant } \\
\text { parameter }\end{array}$}} & \multicolumn{5}{|c|}{ Study 2010} & \multicolumn{3}{|c|}{ LT 2012} \\
\hline & & & var. V & & & $\mathrm{H} 4$ & & & \\
\hline $\begin{array}{l}\text { line speed limit (max. } \\
\text { train speed) }\end{array}$ & $\begin{array}{l}V \\
{[\mathrm{~km} / \mathrm{h}]}\end{array}$ & 300 & 330 & 350 & 350 & 350 & 350 & 300 & 350 \\
\hline $\begin{array}{l}\text { standard speed of the } \\
\text { slowest trains }\end{array}$ & $\begin{array}{l}V_{\min } \\
{[\mathrm{km} / \mathrm{h}]}\end{array}$ & 140 & 160 & 160 & 200 & 200 & 200 & 300 & 350 \\
\hline max. cant & $\begin{array}{l}D_{\max } \\
{[\mathrm{mm}]}\end{array}$ & 180 & 173 & 163 & 157 & 65 & 150 & 180 & 170 \\
\hline max. cant deficiency & $\begin{array}{l}I_{\max } \\
{[\mathrm{mm}]}\end{array}$ & 150 & 100 & 100 & 80 & 80 & 130 & 150 & 80 \\
\hline max. cant excess & $\begin{array}{l}E_{\max } \\
{[\mathrm{mm}]}\end{array}$ & 109 & 109 & 109 & 80 & 18 & 80 & $-*$ & $-*$ \\
\hline min. radius of curve & $\begin{array}{l}R_{\min } \\
{[\mathrm{m}]}\end{array}$ & 3220 & 4720 & 5500 & 6100 & 10000 & 5170 & 3220 & 5790 \\
\hline $\begin{array}{l}\text { type of transition } \\
\text { curve and cant transi- } \\
\text { tion }\end{array}$ & & $\begin{array}{l}\text { non- } \\
\text { linear }\end{array}$ & $\begin{array}{l}\text { non- } \\
\text { linear }\end{array}$ & $\begin{array}{l}\text { non- } \\
\text { linear }\end{array}$ & non-linear & non-linear & $\begin{array}{l}\text { non- } \\
\text { linear }\end{array}$ & $\begin{array}{l}\text { non- } \\
\text { linear }\end{array}$ & $\begin{array}{l}\text { non- } \\
\text { linear }\end{array}$ \\
\hline $\begin{array}{l}\text { max. longitudinal gra- } \\
\text { dient }\end{array}$ & $\begin{array}{l}S_{\max } \\
{[\%]}\end{array}$ & 20 & 20 & 20 & 20 & 20 & 20 & 35 & 35 \\
\hline track construction & & slab & slab & slab & ballasted & ballasted & slab & slab & slab \\
\hline $\begin{array}{l}\text { max. length of tunnel } \\
\text { by TSI }\end{array}$ & $\begin{array}{l}L_{T, \max } \\
{[\mathrm{km}]}\end{array}$ & 5 & 5 & 5 & 5 & 5 & 5 & 20 & 20 \\
\hline
\end{tabular}

* Cant excess evaluation is considered only in large longitudinal gradients when high speed train cannot reach line speed

TABLE 1. Main design parameters of Study 2010 and LT 2012.

Evaluation of variants Study 2010 and LT 2012 shows that the daily costs of Study 2010 are about a million CZK higher (see Table 2 and Figure 1). The daily costs for buying trainsets are $3 \%$ higher for variant LT 2012 - it considers only the high speed multiple units operation with the speed $300 \mathrm{~km} / \mathrm{h}$ or $350 \mathrm{~km} / \mathrm{h}$. Both variants have the same investment infrastructure costs. Variant LT 2012 assumes slab track, which is more expensive than ballasted track, but this variant saves money on building tunnels and bridges. Thanks to the maximal longitudinal gradient $35 \%$ (in comparison with $20 \%$ in Study 2010) these structures are less frequent in this variant LT 2012. Slab track also resulted in a 7\% cost decrease, because maintenance costs are reduced. A negligible part of the costs includes: trainsets cleaning, overheads and investment to estates (estates costs are divided into long time).

The different composition of costs for both of the variants causes different cost ratios between the infrastructure manager and railway transportation operator. In the Study 2010, the railway transportation operator spends $60 \%$ of overall costs. In the variant LT 2012, the railway transportation operator spends $67 \%$ of overall costs. This distribution also has an impact on infrastructure manager's daily costs for the unit of line length and the railway transportation operator daily costs, because the costs are $22 \%$ lower for variant LT 2012 and, because the costs are $14 \%$ higher for variant LT 2012. The difference in infrastructure investment costs are approximately three billions CZK.

\section{Conclusion}

There is no doubt that the building and operation of a high speed railway system is one of the key steps to improve railway transportation functionality [6]. We can testify this not only in the states of Western Europe or Japan, but also in Morocco and Saudi Arabia. There are many different approaches to the relationship between current conventional networks and newly built high speed networks. These approaches are based on demographical structure, terrain configuration, conventional network parameters and the overall goals for railway transportation [7]. The choice of approach affects the relationship between the infrastructure and the train parameters. The different approaches to conventional/high speed train integration were described in the first part of this paper and applied on the planned high speed railway line Praha - Brno, which should create the best transport route in the Czech Republic. The best variant was chosen according to the total intern costs - investment and operational. For the purpose of calculation unit costs were used $t$. The values of these costs are different, according to what sources and assumptions are made and are subject to debate [8]10, but every cost which was used, is considered as representative and approximately the correct value. Not only was a theoretical model made, but a fully functional and editable model was created for the final calculation of costs.

The application of the model has confirmed the assumption that a high speed railway line, for use exclusively for high speed trains has the same or lower 


\begin{tabular}{|c|c|c|c|c|}
\hline study - variant & \multicolumn{2}{|c|}{ Study 2010 - var.H4 } & \multicolumn{2}{|l|}{ LT 2012} \\
\hline item & costs per day & & costs per day & \\
\hline costs per day & [CZK/day $]$ & [\%] & [CZK/day] & [\%] \\
\hline HS train operation (time costs) & 263571 & 2 & 258844 & 2 \\
\hline train-sets acquisition & 1365766 & 10 & 1713718 & 13 \\
\hline investment to line-section infrastructure & 3086366 & 22 & 2933059 & 22 \\
\hline investment to estates & 11707 & 0 & 11798 & 0 \\
\hline electric power for trains & 3238855 & 23 & 3176694 & 24 \\
\hline HS line infrastructure maintenance & 2521874 & 18 & 1464062 & 11 \\
\hline HS train-sets maintenance & 3542821 & 25 & 3473389 & 26 \\
\hline HS train-sets cleaning and overhead costs & 162182 & 1 & 145023 & 1 \\
\hline sum & 14193142 & & 13176587 & \\
\hline
\end{tabular}

Costs per day of railway transportation subjects:

\begin{tabular}{|c|c|c|}
\hline infrastructure manager & $40 \%$ & $33 \%$ \\
\hline carriers & $60 \%$ & $67 \%$ \\
\hline infrastructure owner & $0 \%$ & $0 \%$ \\
\hline
\end{tabular}

Infrastructure investment costs:

\begin{tabular}{|c|c|c|}
\hline Total investment costs of infrastructure construction [mil. Kč] & 96348 & 93162 \\
\hline total costs of purchase estates [mil. Kč] & 427 & 431 \\
\hline
\end{tabular}

TABLE 2. Costs evaluation of variants.

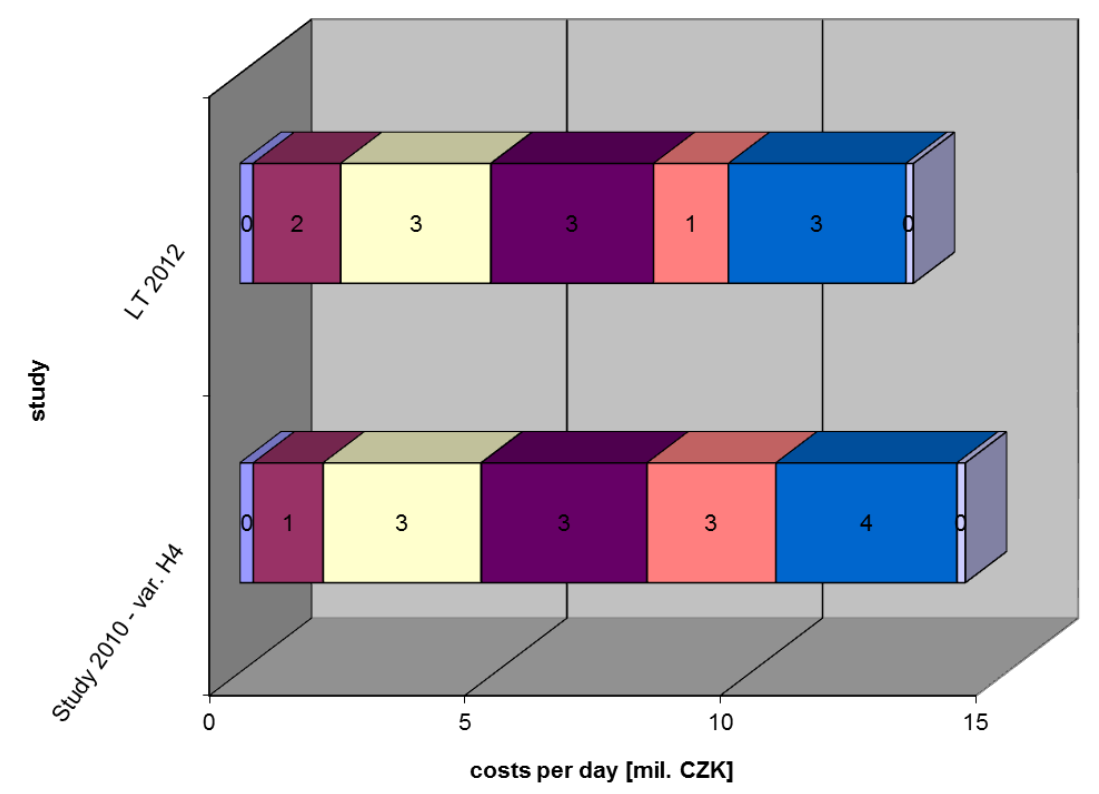


investment costs than line for both high speed and conventional trains (the higher cost for slab track are compensated for by reduced number/length of the tunnels and bridges). A high speed line also has lower cost for infrastructure maintenance but a higher cost associated with buying only high speed multiple units. The costs for a line exclusively for high speed trains (high speed multiple units) is lower in the absolute terms in comparison to line for both high speed and conventional trains. The selection of the optimal variant seems to be clear, but minimization of total internal costs does not have to be the only important parameter. For example, we can decide only according to the total infrastructure manager investment costs. This shows strong connectivity between the railway transportation subsystems and the importance of continuous coordinated planning and design of the whole railway system. After we overcome all of the obstacles, society, as a whole, will be rewarded with a safe, environmentally friendly and highly effective railway system. This is why it is necessary to examine possible parameters (operational conception, line parameters, safety devices, train sets) of the new lines, before we even assign routing studies to the designers. Furthermore, we cannot omit an evaluation of the time period between launching the project and launching its regular operation for all subsystems and their life cycles.

It is possible to conclude that a high speed railway system in the Czech Republic should consist of several line types (or line segments). The parameters of these types should be based on the anticipated types of trainsets (multiple units), which are going to use the system. Some segments should have parameters that fit both conventional trains and high speed trains, while others should be designed only for high speed trains. The individual types of lines should therefore be designed with different parameters. Decisions on the types of high speed lines segments will significantly affect current and future conditions of the conventional railway network, which, once again, shows us strong connectivity between different parts of railway system.

\section{REFERENCES}

[1] L. Týfa. Service of High Speed Railway Systems in Region [Associate Professor Lecture]. Praha: Czech Technical University in Prague, 2013. ISBN 978-80-01-05199-3.

[2] L. Týfa. Nejnovějši trendy v oblasti infrastruktury vysokorychlostnich tratí. In Odborná konference Vysokorychlostni železnični doprava ve světě a v České republice [CD-ROM]. Praha: SUDOP PRAHA a.s., 2007.

[3] Directive EU No. 2008/57/EC on the interoperability of the rail system within the community.

[4] ČSN EN 13803-1:2010. Railway applications - track track alignment design parameters - track gauges 1435 $\mathrm{mm}$ and wider - part 1: Plain line, 2010.

[5] J. Tvrdík. Podmienky pre výstavbu VRT Praha Brno. In 7. Fórum kolajovej dopravy. Bratislava: Spoločnost PSKD - Prevádzka a stavby kolajovej dopravy, 2011. ISBN 978-80-88973-68-3.

[6] J. Ilík, J. Kušnír, R. Čech. Budoucnost české železnice $v$ dokumentech evropské dopravni politiky. Železniční magazín. Praha: M-Presse plus, 2012, roč 18, č 1 . ISSN $1212-1851$

[7] UIC. High speed rail: Fast track to sustainable mobility. Paris: UIC, High Speed Department. 2nd ed. updated. ISBN 2-7461-1452-6.

[8] J. Pohl. Rychlá železniční osobni doprava: díl dvacátý: Náklady a výnosy poprvé. Železniční magazín. Praha: M-Presse plus, 2010, roč 16, č 1. ISSN 1212-1851.

[9] J. Pohl. Rychlá železniční osobni doprava: díl dvacátý první: Náklady a výnosy podruhé. Železniční magazín. Praha: M-Presse plus, 2010, roč 16, č 2. ISSN 1212-1851.

[10] I. C. GmbH, INRETS. Traffic and profitability for a western European high speed train network, 1994. 